\title{
Ciliate feeding: effect of food presence or absence on occurrence of striae in tintinnids
}

\author{
Gerard M. Capriulo, Juan Taveras \& Kenneth Gold
}

Division of Natural Sciences, State University of New York, Purchase, New York 10577, USA

\begin{abstract}
Tintinnid ciliates have been shown to be important components of many marine food webs, and several studies have been conducted to quantify their ingestion rates. The actual mechanism they use for prey capture, however, is not yet known. Extrosomes, membrane bound extrusible bodies subpellicularly located, are common in the ciliated Protozoa, and have diverse functions. Many species of tintinnid have been found to possess striae: cytoplasmic, capsule (extrosome) containing evaginations associated with the oral membranelles. To begin to test the hypothesis that the striae and the associated capsules are involved in prey capture, Stenosemella oliva and several species of the genus Tintinnopsis were used. Tintinnids were field collected and divided into 2 groups, one which was fed, the other unfed for about $20 \mathrm{~h}$, in a series of experiments. Subsequent scanning electron microscopic examinations revealed numerous striae associated with the oral membranelles of the fed group, while the unfed group exhibited a paucity of these structures. Large sac-like bodles were observed in one well-fed individual. It is suggested that the striae and associated capsules may be used to capture prey.
\end{abstract}

\section{INTRODUCTION}

Ciliates are a major component of many marine, estuarine and freshwater planktonic and benthic communities (Vitiello 1964, Fenchel 1969, Hartwig 1973. Sorokin 1977. Heinbokel \& Beers 1979, Beers et al. 1980, Hargraves 1981, Pace \& Orcutt 1981, Capriulo \& Carpenter 1983) and serve as a food source for many larger zooplankton including copepods and juvenile fish (LeBrasseur \& Kennedy 1972, Voronina \& Sukhanova 1976, Capriulo \& Ninivaggi 1982, Robertson 1983, Turner \& Anderson 1983, Stoecker \& Govoni 1984, Stoecker \& Sanders 1985) and foraminiferans (Hemleben et al. 1977). Tintinnid ciliates (class Spirotrichea, order Choreotrichida, suborder Tintinnina; Small \& Lynn 1985) often dominate plankton communities (Gold \& Morales 1975, Hargraves 1981, Capriulo \& Carpenter 1983, Capriulo \& Dexter unpubl.) and remove significant quantities of algae as well as heterotrophic biomass from many marine ecosystems (Heinbokel \& Beers 1979, Capriulo \& Carpenter 1980, 1983, Rassoulzadegan \& Etienne 1981, Landry \& Hassett 1982). Additionally, certain tintinnids, such as Favella sp., selectively feed on dinoflagellates including those responsible for toxic red tides (Stoecker et al. 1981).

Recent findings suggest that at least in certain en- vironments tintinnid community ingestion rates are equal to those of the copepod community (Capriulo \& Carpenter 1983). The feeding impact of these ciliates coupled with their short generation times, high abundances and high gross growth efficiencies clearly highlights this group as a major component of the planktonic (as well as the benthic) food web (Vitiello 1964, Fenchel 1969, Rassoulzadegan 1978, Hargraves 1981, Capriulo 1982, Capriulo \& Carpenter 1983).

Despite the realization that ciliates are major players in aquatic microbial food webs, quantification of their feeding rates is rare. Ingestion and clearance rates for tintinnids have been reported by several workers (Spittler 1973, Blackbourn 1974, Heinbokel 1978a, b, Rassoulzadegan 1978, Rassoulzadegan \& Etienne 1981, Stoecker et al. 1981, Capriulo 1982, Capriulo \& Carpenter 1983), all of whom demonstrated that these ciliates were capable of selective feeding. The mechanism(s) by which food is actually captured and subsequently eaten by the tintinnids, however, remains unknown. Many ciliates use a specialized method of obtaining food which involves directly contacting prey items. This predatory mode of feeding requires production of special organelles known as extrosomes which are defined by Corliss (1979) as membrane-bound extrusible bodies usually sub-pellicularly located. Tintinnids have been found to pos- 
sess what appear to be extrusible bodies known as capsules. Their capsules are contained within striae which are cytoplasmic evaginations associated with the adoral membranelles (Entz 1929, Laval 1971, 1972 Gold 1979, Laval-Peuto et al. 1979). These striae have been found to contain numerous capsules (Laval 1971, Gold 1979, Laval-Peuto et al. 1979). The capsules show the same general organizational pattern in all species. They are grossly spherical in appearance, show a conical anterior pole distinct from a rounded posterior pole and the contents are electron dense and finely granular (Laval 1971, Gold 1979, Laval-Peuto et al. 1979). LavalPeuto et al. (1979) also found that the capsules in Tintinnopsis parva exhibited distinct orientation in a cell with the anterior pole always oriented towards the cell membrane, and noted that the striae are just one of several structures by which the capsules are positioned in proximity to the adoral membranes. Capsules with a polar appearance have also been found in Parafavella gigantea and Favella ehrenbergï (Hedin 1975).

A definitive function has not yet been ascribed to the striae or capsules found in tintinnids. Gold (1979) noted the abundance of capsules found inside the striae and the proximity of the striae to the oral area and proposed a mechanism whereby the capsules, protected only by the perilemma and cell membrane, rupture when brought in contact with prey organisms, subsequently releasing their contents to act upon the prey.

If, indeed, the striae are associated with tintinnid feeding, we hypothesize that food presence or absence would alter the numbers of striae in tintinnids, i.e. that the amount of food and the number of striae present would be functionally related. The research described here examines the relation between the presence or absence of food and the occurrence of striae in Tintinnopsis spp. and Stenosemella oliva.

\section{MATERIALS AND METHODS}

Several experiments were carried out, one on tintinnids collected from the surface waters of the New York Bight (NYB) and the others on tintinnids collected from the lower Hudson River Estuary at a station near the Tappan Zee Bridge (HRT). Tintinnids were collected by towing a $20 \mu \mathrm{m}$ mesh, $0.25 \mathrm{~m}$ diameter plankton net through the surface water. Transportation of the water samples to the laboratory took only about 1.5 to $30 \mathrm{~min}$. with no changes in temperature. Tintinnids were immediately micro-pipetted out of the water sample (about 1000 individuals) and transferred into either NYB or HRT filtered water. Following pipetting, the tintinnids were divided into 2 groups, one which was fed and the other unfed, and contained within separate
$15 \mathrm{ml}$ screw cap test tubes or small volume Petri dishes (about $15 \mathrm{ml}$ size) at an initial concentration of about 70 cells $\mathrm{ml}^{-1}$. Logarithmically growing cultures of one of 2 flagellated algae, Isochrisis galbana or Dunaliella tertiolecta (initial concentrations between approximately $10^{3}$ and $10^{5} \mathrm{ml}^{-1}$ ), were used as food for the NYB experiment and HRT experiments, respectively. All tubes were incubated in the dark $\left(18^{\circ} \mathrm{C}\right.$ for $\mathrm{HRT}$ and $10^{\circ} \mathrm{C}$ for $\mathrm{NYB}$ ) for about $20 \mathrm{~h}$. After this time actively swimming tintinnids from both groups were micropipetted out and fixed in Kannovsky's fixative (Karnovsky 1965, Gold 1980) in beem capsules, to be prepared for scanning microscopy. Fixation was followed by a 30 min rinsing in cacodylate buffer. Post fixation was carried out in $1 \%$ osmium tetroxide in cacodylate buffer for $45 \mathrm{~min}$ followed by dehydration in a graded ethanol series, for 15 min in each. Tintinnids were then transferred into $1: 1$ ratio $100 \%$ ethanol $/ 100 \%$ acetone, and then into $100 \%$ acetone twice, for 15 min each. Transfer to anhydrous acetone prior to critical point drying in $\mathrm{CO}_{2}$ was found to be beneficial (Bomar SPC-900/EX critical dryer was used for the HRT experiments and a Sorvall unit for the NYB). The entire process was carried out in beem capsules covered with $20 \mu \mathrm{m}$ nitex screening on both top and bottom. The specimens were coated with gold/ palladium for a total of $6 \mathrm{~min}$ at $9 \mathrm{~V}$ in a Hummer JR sputter coater. Coating was carried out in 30 s episodes followed by $90 \mathrm{~s}$ intervals for cooling, to prevent specimen burn. After a total of 2 min the sputter coater was turned off and air was admitted into the chamber, to prevent additional heating. Tintinnids were examined in a Super III A IAI scanning microscope (HRT) and a JSM-35U (JEOL, USA) scanning microscope (NYB).

\section{RESULTS}

Scanning electron microscope (SEM) examination of fed Tintinnopsis beroidea from NYB revealed numerous striae associated with the adoral membranelles (Fig. $1 \& 2$ ). Few striae could be found in the unfed group (Fig. 3). Three follow-up experiments carried out on several species of the genus Tintinnopsis from HRT resulted in similar findings. Numerous striae were found associated with the oral membranelles of the fed groups (Fig. 4 to 10) while the unfed organisms consistently exhibited a paucity of these structures (Fig. 11 to 15). In some cases tintinnids from the unfed group were almost completely devoid of any striae (Fig. 12). In those unfed individuals where striae were found they typically were observed close to the base of the membranelles (Fig. 13, 14 \& 15), and in lesser amounts, as compared to the fed individuals where the striae were stretched out over the entire length of the 
Fig. 1 \& 2. Tintinnopsis beroidea. Membranelles and associated striae under fed and unfed conditions. Fig. 1 Striae condition representative of the general findings for the fed individuals. Arrow indicates sac-like body discussed in the text. Fig. 2. Higher magnification of the striae of a fed individual. Arrow indicates apparent cytoplasmic origin of the striae. Scale bars $=1 \mu \mathrm{m}$

Fig. 3. Tintinnopsis beroidea. Micrograph representative of the best case of striae production in the unfed group. Other individuals were completely devoid of any recognizable striae. Scale bars $=1 \mu \mathrm{m}$
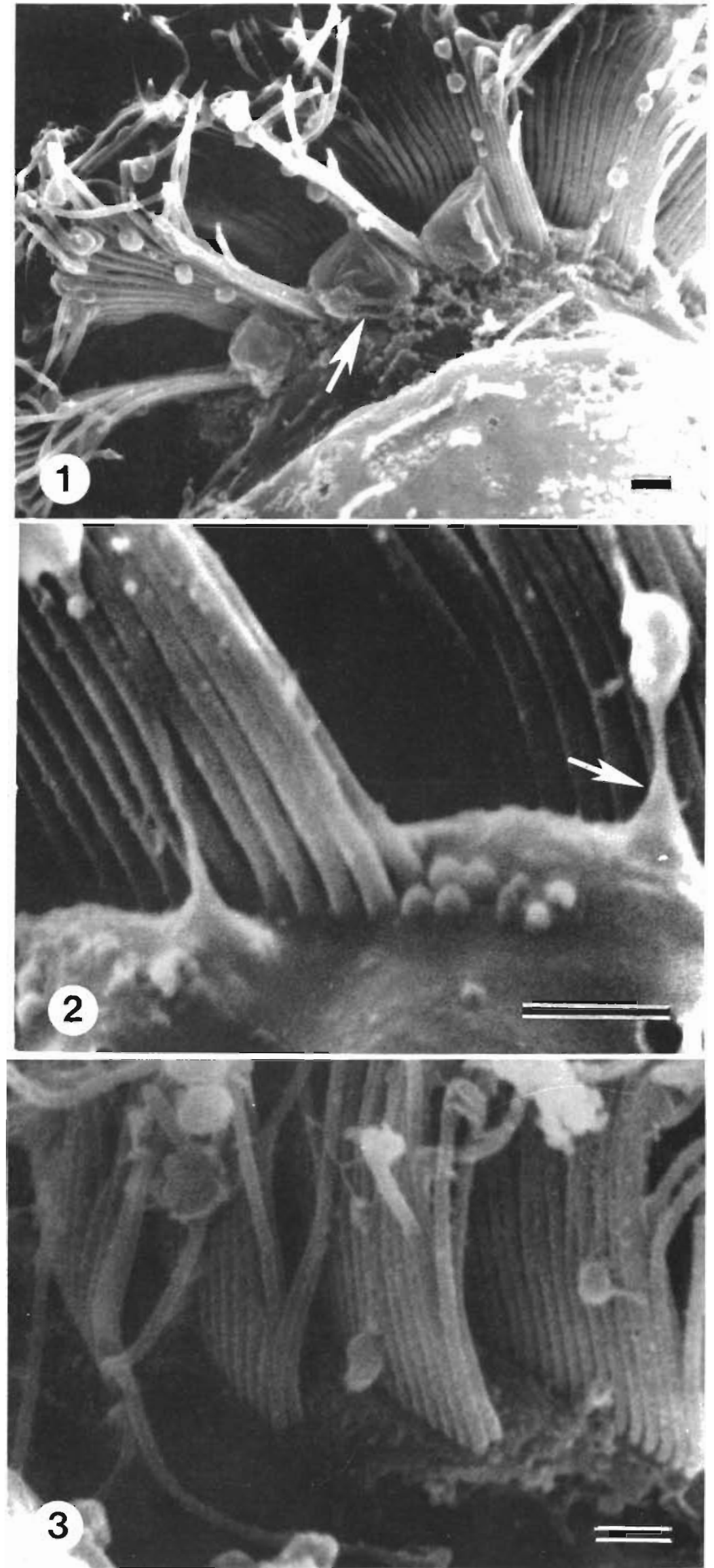

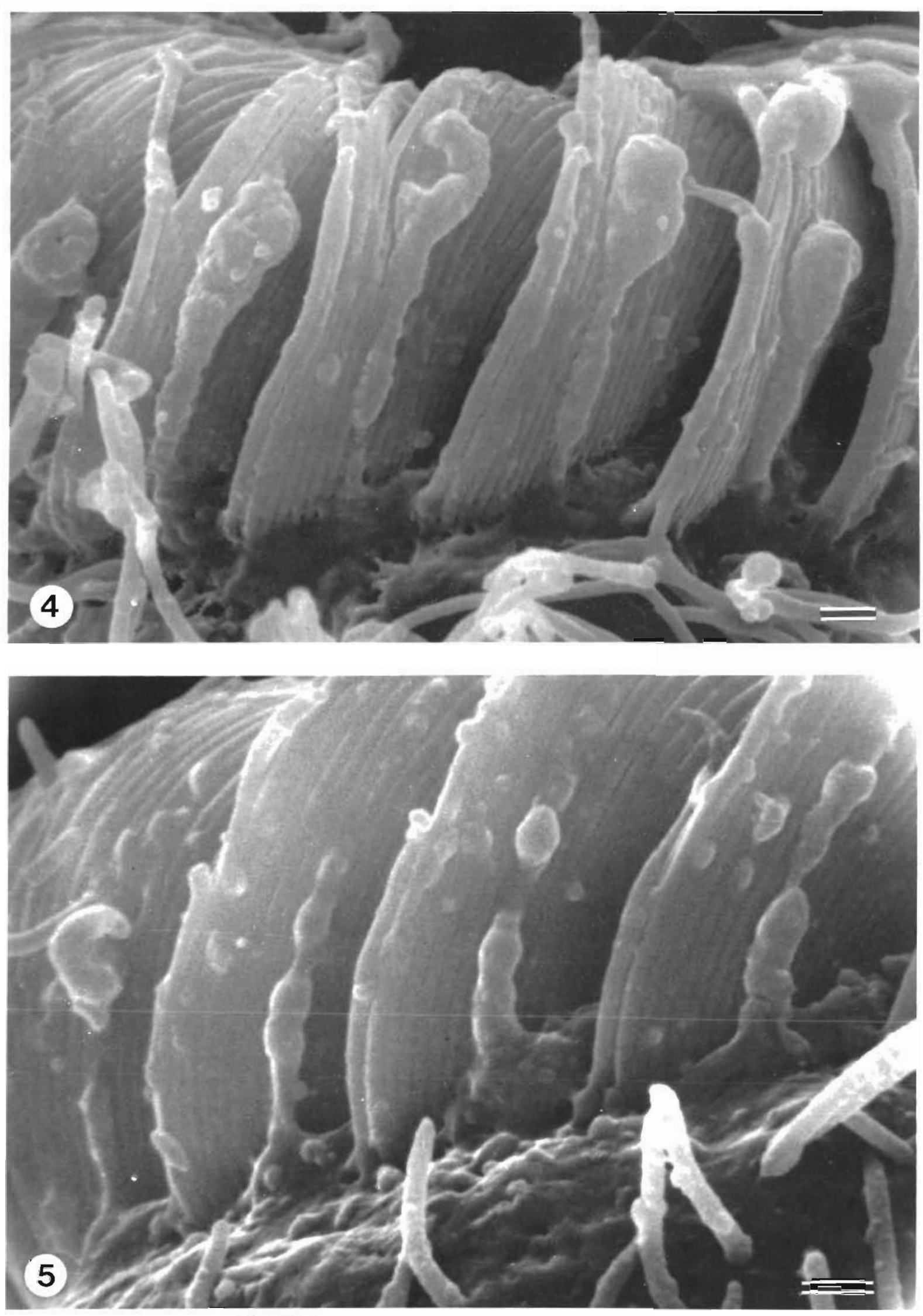

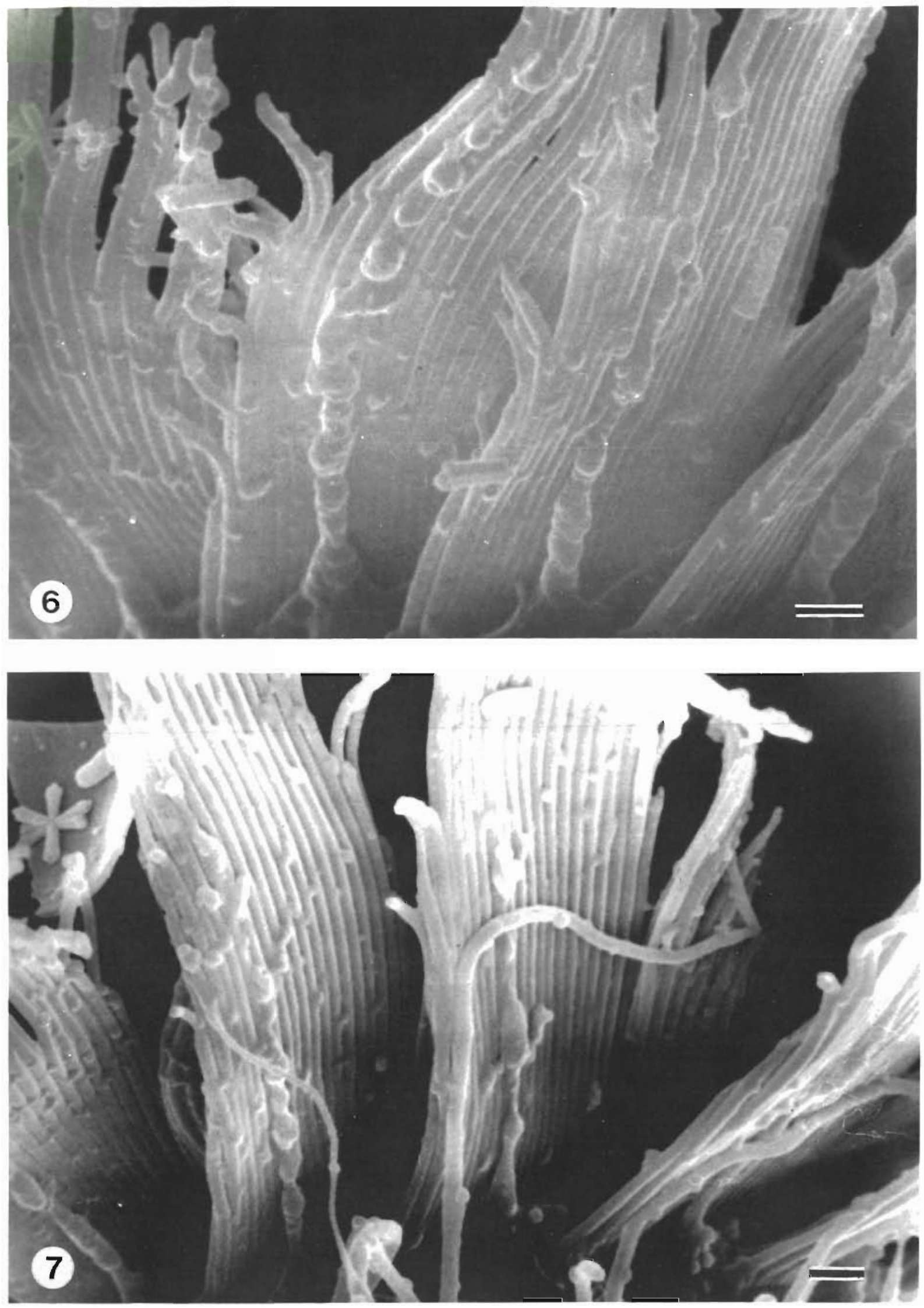

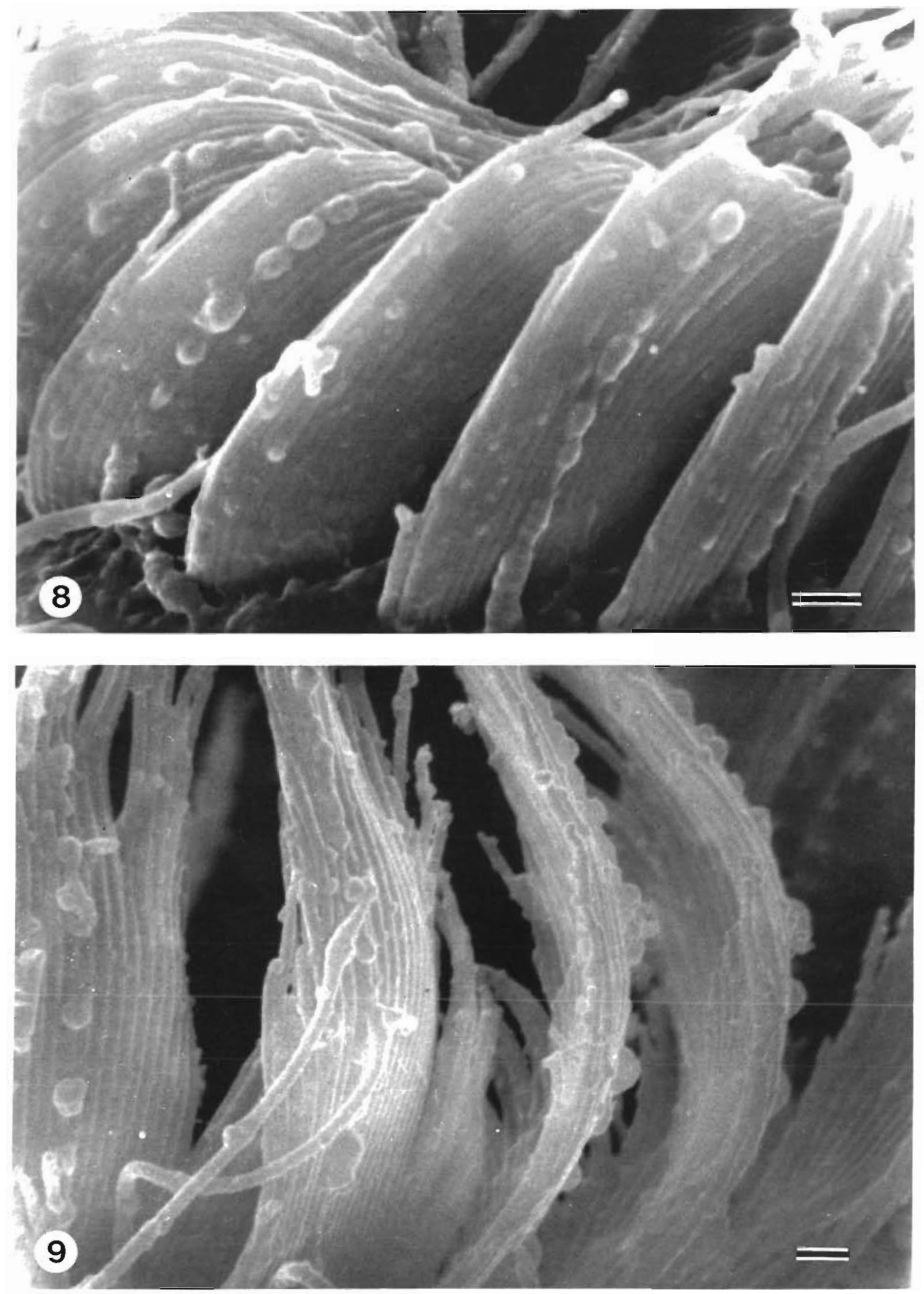


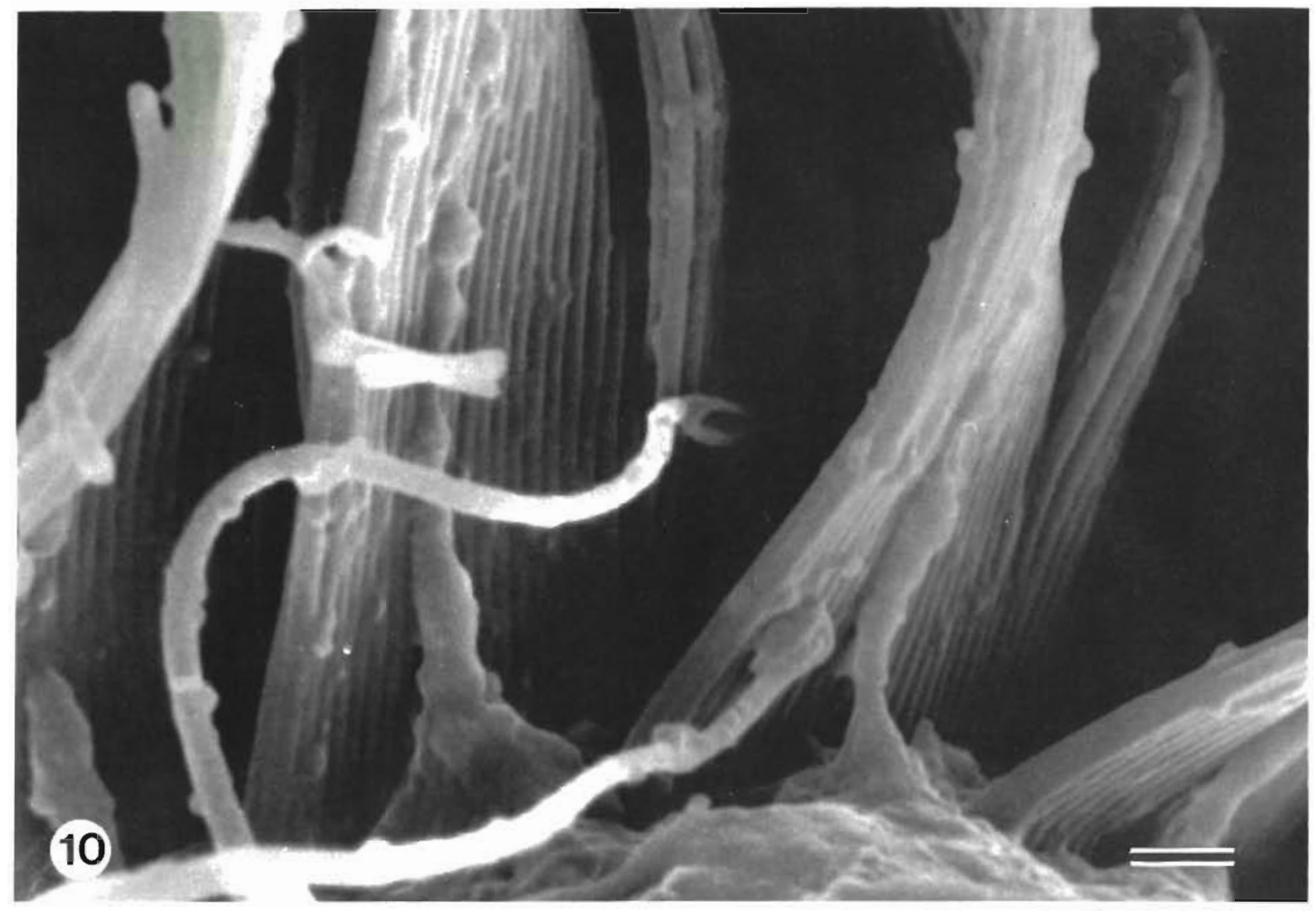

Fig. 4 to 10. Tintinnopsis spp. and Stenosemella oliva. Scanning electron micrographs of fed individuals showing the numerous striae associated with the oral membranelles. Scale bars $=1 \mu \mathrm{m}$

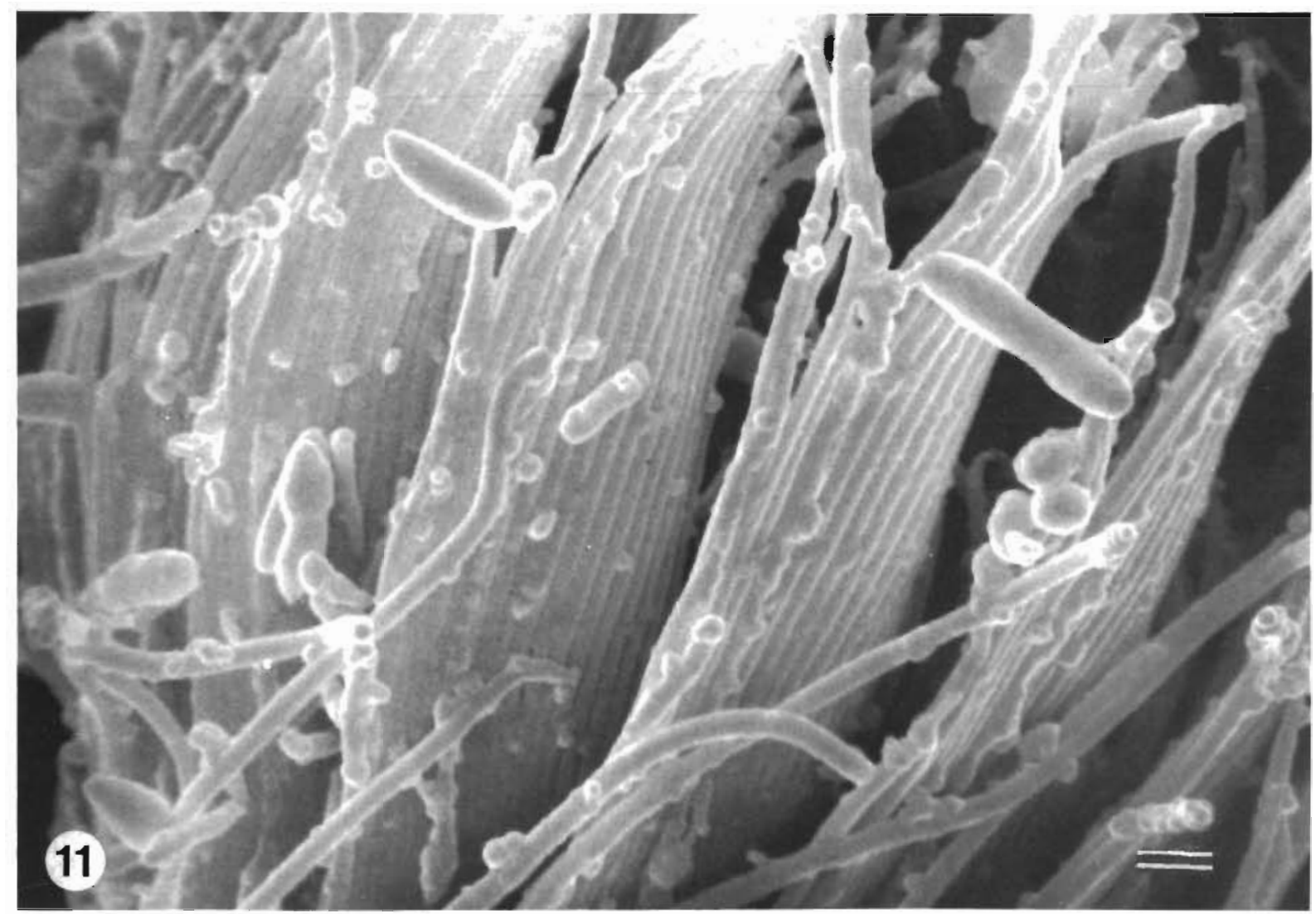



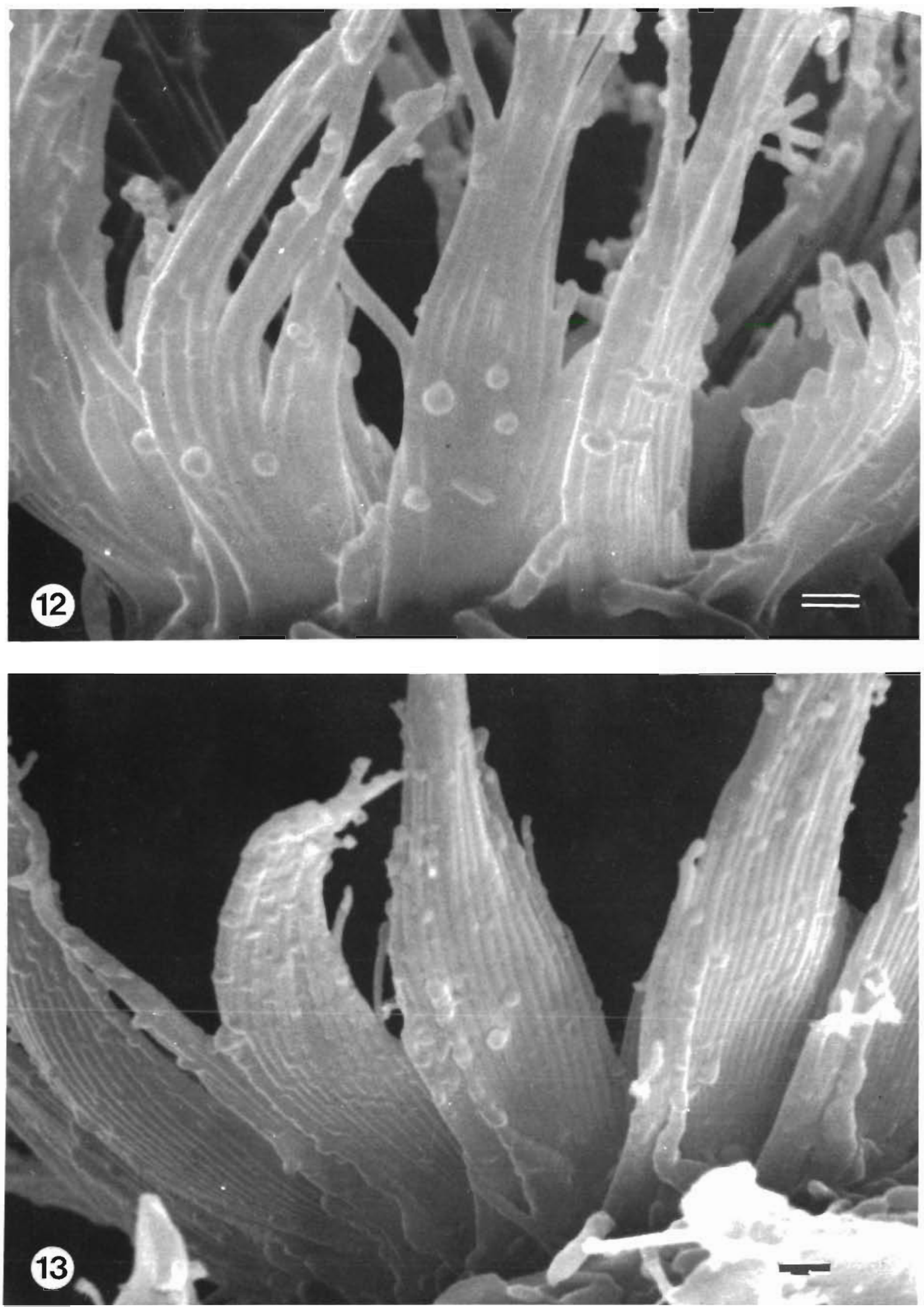

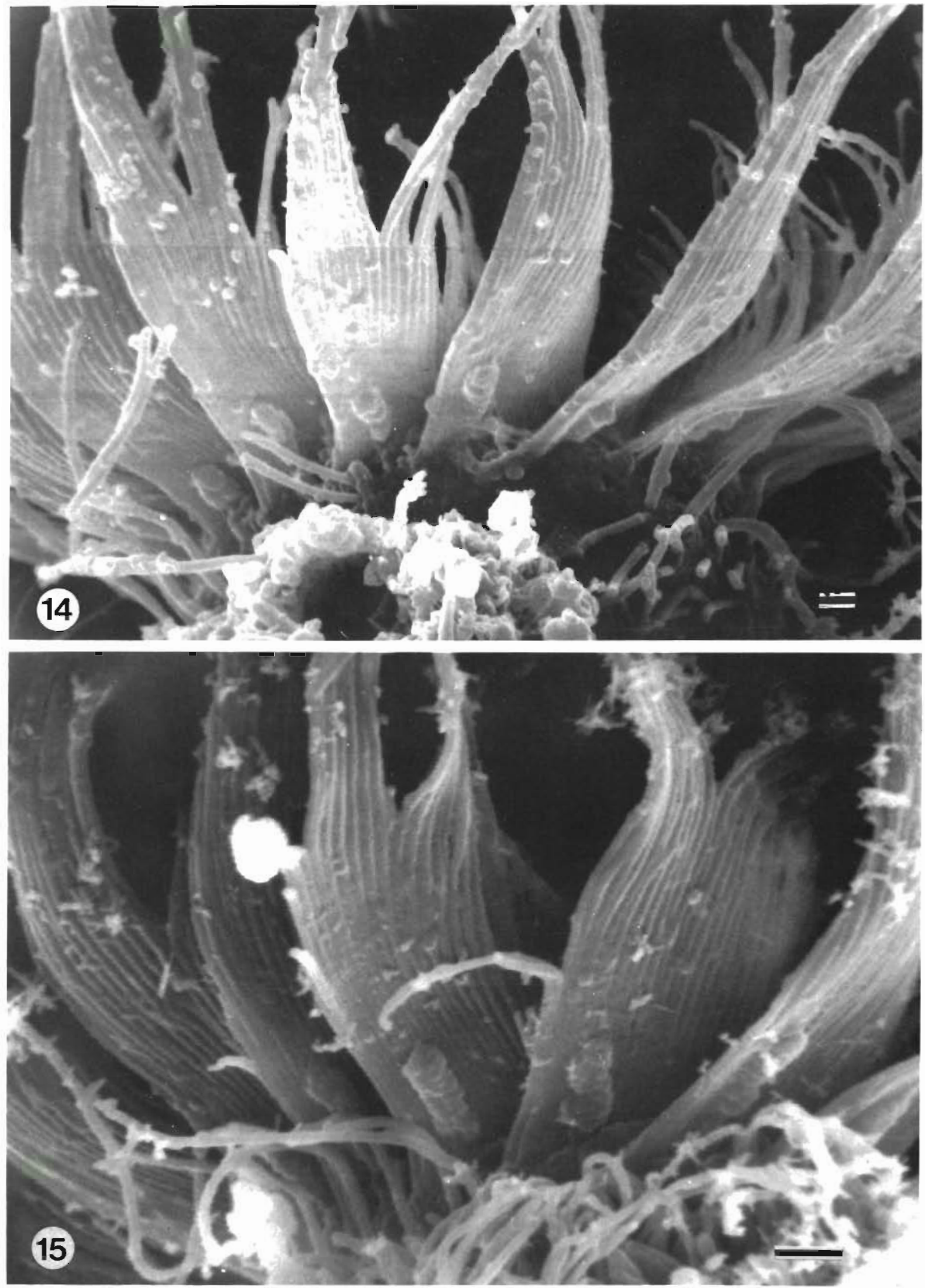

Fig. 11 to 15. Tintinnopsis spp. and Stenosemella oliva. Scanning electron micrographs of starved individuals showing few or no striae associated with the oral membranelles. Scale bars $=1 \mu \mathrm{m}$ 
ciliary membranelles from base to tip (Fig. 4, 6, 8, 9 \& 10). In all organisms observed only one 'beaded' string of striae were found per membranelle and they always occurred toward the outside of the membranelles rather than toward the mouth side.

To statistically test for differences in number of striae present in fed and unfed organisms individual beads of striae were enumerated per membranelle of a single species of the tintinnid Stenosemella oliva. A single classification analysis of variance test was carried out on the data to examine for differences in number of striae per membranelle for the fed and unfed treatments. Results indicate that the fed individuals had significantly more striae (average of 10.9 ) than did the unfed ciliates (average of 3.0) (Table 1), at the $<0.001$ level of significance. These results demonstrate that the quantity of striae present in tintinnids is fooddependent.

Table 1. Stenosemella oliva. Results of a single classification analysis of variance test (unequal sample sizes) for significant differences in number of striae present per membranelle in fed and unfed tintinnids. In all, 38 membranelles ( 23 for the fed and 15 for the unfed) were examined for this statistical test (total sample size $n=38$ ). Range of striae per membranelle in fed individuals was 9 to 17 , with a corresponding range of 1 to 9 in unfed individuals

\begin{tabular}{lcccc|}
\hline $\begin{array}{l}\text { Source of } \\
\text { variation }\end{array}$ & $\begin{array}{c}\text { Degrees of } \\
\text { freedom }\end{array}$ & $\begin{array}{c}\text { Sum of } \\
\text { squares }\end{array}$ & $\begin{array}{c}\text { Mean } \\
\text { square }\end{array}$ & $F$ \\
\hline Among groups & 1 & 568 & 568 & $82^{*}$ \\
Within groups & 36 & 249 & 6.92 & \\
Total & 37 & & & \\
- Significant at the $<0.001$ level & & \\
\hline
\end{tabular}

\section{DISCUSSION}

Despite the realization that ciliates are major players in aquatic microbial food webs, the actual mechanisms by which food is captured and subsequentiy eaten are poorly understood. One reason for the lack of understanding is the extensive diversity of the oral apparatus among ciliates. The nature of the paroral (haplokinety or undulating membrane) and adoral ciliature surrounding the cytosome (mouth), and the degree of oral development exerts a major influence on whether a particular organism is a passive filter feeder or a more active predator (Nisbet 1984).

Fenchel (1980a, b, c, d) suggested that many ciliates act as suspension feeders employing certain cilia to create feeding currents which pass water over and through ciliary organelles which retain prey by means of a sieving process. The Oligohymenophoreans (in particular Hymenostomes such as Glaucoma: Fenchel \& Small 1980, and the peritrichs) are good examples of filter feeders.

Some ciliates have simple mouths whose cilia are almost indistinguishable from somatic cilia, while others have very elaborate oral membranelles. The cytostome itself may be shallow without a ciliated buccal or vestibular area (e.g. subphylum Rhabdophora: Small \& Lynn 1985), in which case the ciliate 'gulps' in food, or it may be deep and well developed with a kinetid lined vestibulum (e.g. Caelosmides marina) that swirls food into the cytostome and down the cytopharynx (Sieburth 1979, Small \& Lynn 1985).

Once food is captured, by whatever mechanism, it must be passed into the cell. This is accomplished either by phagocytosis through a large unciliated surface of cell membrane (e.g. certain karyorelicteans), through a permanent cytostome (Small \& Lynn 1985), or as is the case for suctorians, which lack a permanent mouth, through the use of tentacles armed with haptocysts (extrusible bodies used in food capture, see below) to capture and lyse their prey (Nisbet 1984).

Capriulo (1982) described the effect of food concentration, size and composition on the feeding behavior of several species of field-collected tintinnids and suggested, based on his data as well as that of Hedin (1976), that short-time-scale (days), prey-size-induced changes in the size of the cytostome of these ciliates may routinely occur. Such changes would alter an organism's feeding efficiency and determine what size prey items could be eaten.

\section{Ciliate extrosomes}

In general the occurrence of extrosomes, membranebound extrusible bodies subpellicularly located, is common in the ciliated Protozoa (Sleigh 1973, Corliss 1979). Many types of extrosomes exist including: conocysts, cnidocysts, cyrocysts and rhabdocysts (of generally unknown function), clathrocysts (involved in cyst wall formation), mucocysts (containing a dischargeable mucus mass), trichocysts and fibrocysts (explosive organelles containing fibrous shafts), haptocysts (containing lytic enzymes) and toxicysts and pexicysts (containing paralytic and proteolytic enzymes used to capture prey: Corliss 1979).

The striae of tintinnids are cytoplasmic evaginations which contain capsules (Fig. 16, 17 \& 18) which we believe are the extrosomes of tintinnids. The capsule structure (Fig. 17 from Laval-Peuto et al. 1979) is polar with definite apical ends and an electron-dense, granular interior appearance. The capsules resemble haptocysts and microtoxicysts (Laval 1971) and might 
even be a type of modified microtrichocyst. Because of their proximity to the mouth, the capsules found inside them, and the fact that their occurrence is correlated

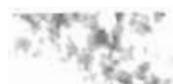

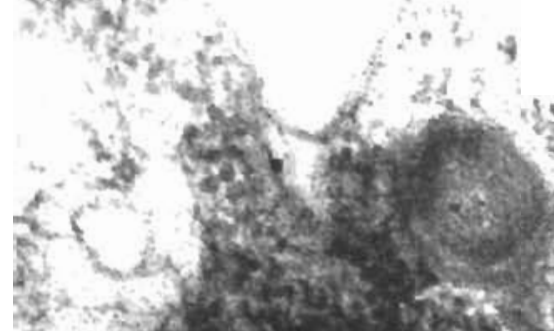

with food presence or absence, we believe that the striae are involved in prey capture. They may represent a mechanism for increasing the probability of

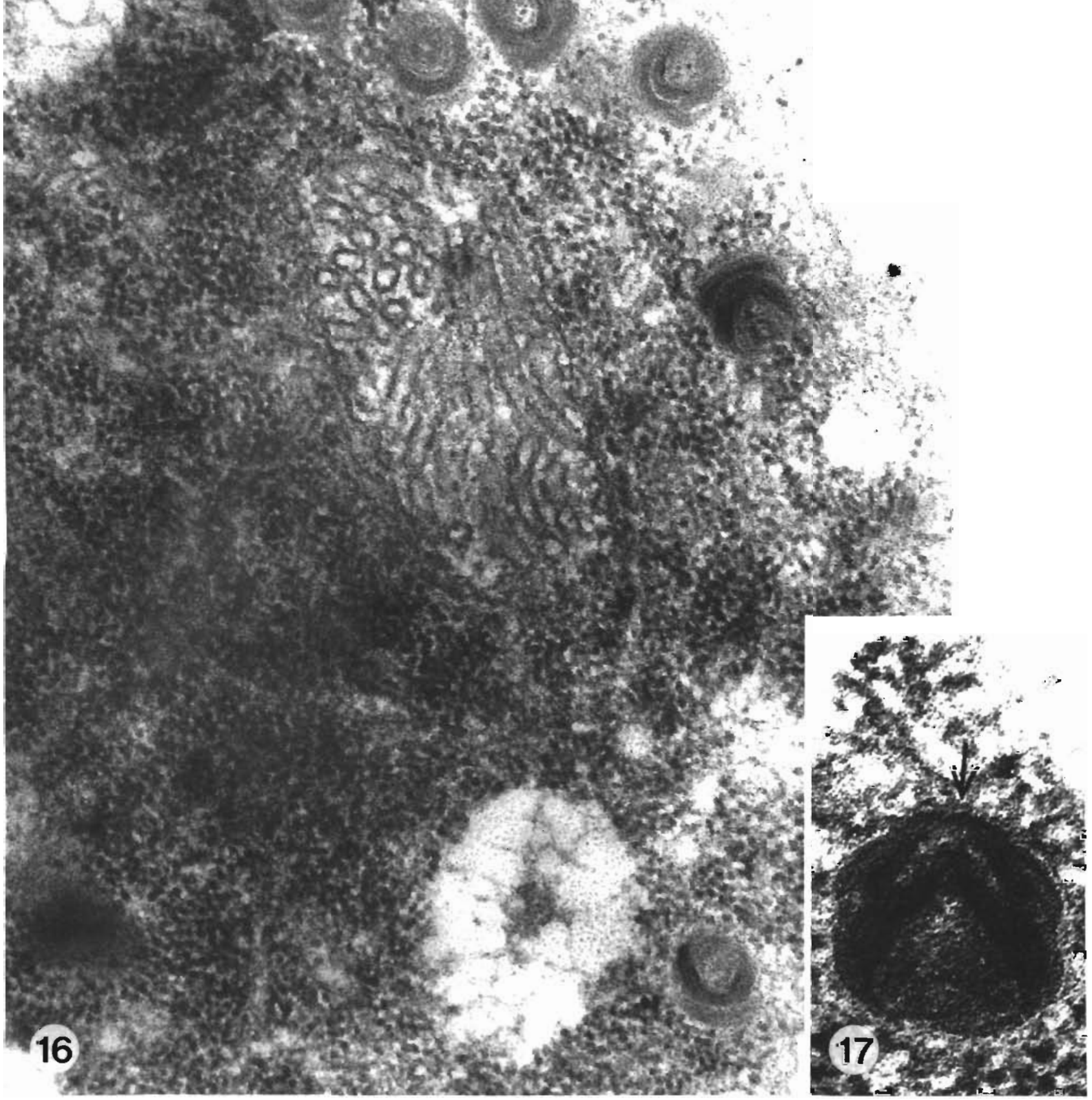

Fig. 16. TEM section of a tintinnid showing several capsules. Note the polar appearance of all the capsules. $\times 81,000$

Fig. 17. Tintinnopsis parva. Transmission micrograph of a capsule showing the distinctive polarity and densely granular, arrow shaped material of the capsule. The capsules resemble haptocysts and microtoxicysts, but could also be a kind of microtrichocyst. (From Laval-Peuto et al. 1979) × 226,800 


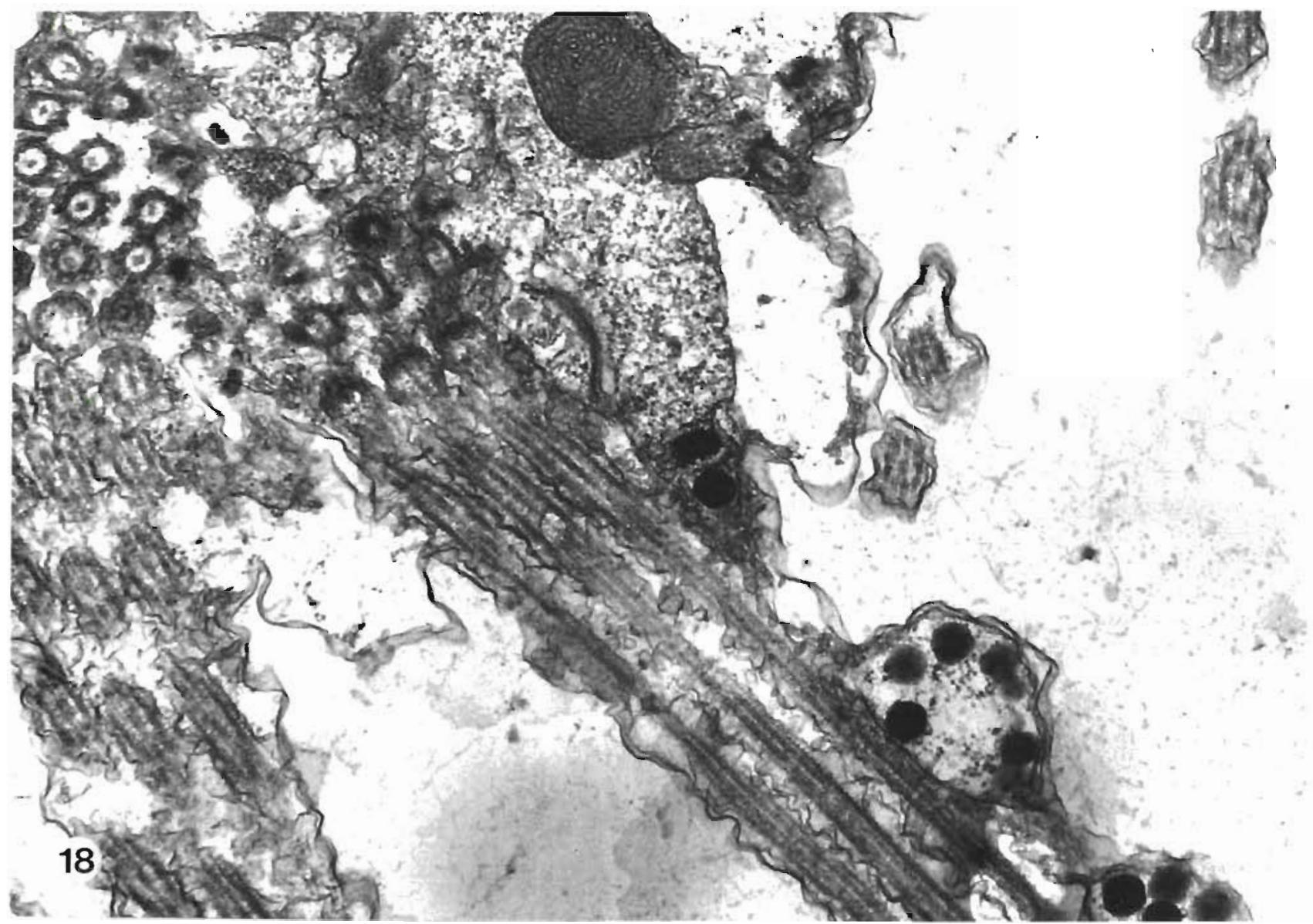

Fig. 18. Tintinnopsis parva. Longitudinal section through the base of an oral membranelle showing the striae and capsules contained within. $\times 26,600$

contact with prey of both the capsules (by bringing more of them closer to potential prey) and the ciliary membranelles (by increasing their effective search radius). While we favor this argument, the possibility that measured differences in the quantity of striae could be representative of poor physiological condition due to starvation (i.e. for energetic and nutritional reasons independent of food capture) cannot yet be ruled out. The occurrence of the sac-like body at the base of the membranelle (Fig. 1) is interesting. We observed this structure only once in Tintinnopsis beroidea although it has occassionally been observed in other tintinnids (Laval-Peuto pers. comm.). The size of the 'sacs' noted in this study is approximately equal to that of the striae found at the base of the membranelles of $T$. parva (Fig. 11 of Gold 1979). Close examination of Fig. 1 of this study suggests that the 'sacs' might be the points of origin of the smaller striae, and may in fact themselves be nothing more than large striae, perhaps containing higher concentrations of capsules, from which smaller units break away as they move up a membranelle. Unless continual replacement of 'sac' material occurs, the size of a particular sac would diminish over time. This may explain the absence of a 'sac' at the base of the membranelle to the extreme right of Fig. 1, even though striae are present.

The presence of striae is a response to food. If their production is biochemically stimulated, then not producing them in large quantities when prey are rare would allow the cells to save energy. This response would be of evolutionary advantage, since the energy saved would allow the cells to survive longer in the absence of food. However, minimal striae production in the absence of food would also be beneficial to the tintinnid (this notion of minimal occurrence is supported by our data which indicates that about 3 striae per membranelle were present in unfed individuals). Should a tintinnid come in contact with food, they would have the capability for some prey capture if a small number of striae and capsules were available for use.

The occurrence of the striae and capsules as probable organelles for prey capture in tintinnids suggests that it is unlikely that tintinnids solely act as passive filter feeders. Rather, they 'search' their surroundings, probably using feeding currents, as well as other 
methods, to bring prey towards them. Once in contact with the oral membranelles some food items (particularly non-motile ones) are likely to be trapped among the oral ciliature or passively enter the cytostome (as part of 'dead zones' of no water current near the cytostome or within the bucal cavity: Nisbet 1984) while other prey are trapped by the action of the striae/ capsules. The trapping may be mediated by enzymatic action, projectile discharge or adhesion.

It is unlikely that all food encountered is captured. Certainly prey size and degree of vigor will effect capture retention efficiencies. Also, the ability of the tintinnid cytostome to accomodate a given prey item is important (Capriulo 1982). Lastly, the likely probability that tintinnids are capable of chemosensory activity (something which Capriulo has anecdotally observed on many occasions) will change encounter frequencies in a non-random way. Chemosensory hunting coupled with active predation via extrosomal discharge surely will force us to view these protistan predators in a new light.

Acknowledgements. This research was supported by a grant from the Hudson River Foundation for Science and Environmental Research. We are deeply indepted to Dr. Jan Factor for his help and expertise concerning the scanning electron micrographs, as well as his generosity with various related supplies, and to Dr. Michèle Laval-Pento for challenging discussions and suggestions concerning this contribution.

\section{LITERATURE CITED}

Beers, J. R., Reid, F. M., Stewart, G. L. (1980). Microplanktonic population structure in southern California nearshore waters in late spring. Mar. Biol. 60: 209-226

Blackbourn, D. J. (1974). The feeding biology of tintinnid Protozoa and some other inshore microzooplankton. Ph.D. thesis. Univ. British Columbia

Capriulo, G. M. (1982). Feeding of field collected tintinnid micro-zooplankton on natural food. Mar. Biol. 71: 73-86

Capriulo, G. M., Carpenter, E. J. (1980). Grazing by 35 to 202 $\mu \mathrm{m}$ microzooplankton in Long Island Sound. Mar. Biol. 56: 319-326

Capriulo, G. M., Carpenter, E. J. (1983). Abundance, species composition and feeding impact of tintinnid micro-zooplankton in central Long Island Sound. Mar. Ecol. Prog. Ser. 10: 277-288

Capriulo, G. M., Ninivaggi, D. V. (1982). A comparison of the feeding activities of field collected tintinnids and copepods fed identical natural particle assemblages. Annls Inst. océanogr. Paris 58 (S): 325-334

Corliss, J. (1979). The ciliated Protozoa. Pergamon Press, Oxford

Entz, G. Jr. (1929). Über Struktur und Funktion der Membranulae der Tintinniden, speziell von Petalotricha ampulla. 10th Cong. Int. Zool., p. 887-895

Fenchel, T. (1969). The ecology of marine microbenthos. 4. Structure and function of the benthic ecosystem. Ophelia 6: $1-182$
Fenchel, T (1980a). Relation between particle size selection and clearance in suspension feeding ciliates. Limnol. Oceanogr. 25: 733-738

Fenchel, T. (1980b). Suspension feeding in ciliated Protozoa: functional response and particle size selection. Microb. Ecol. 6: 1-11

Fenchel, T. (1980c). Suspension feeding in ciliated Protozoa: feeding rates and their ecological significance. Microb. Ecol. 6: 13-25

Fenchel, T (1980d). Suspension feeding in ciliated Protozoa: structure and function of feeding organelles. Arch. Protistenk. 123: 239-260

Fenchel, T., Small, E. B. (1980). Structure and function of the oral cavity and its organelles in the hymenostome ciliate Glaucoma. Trans. Am. microsc. Soc. 99: 52-60

Gold, K. (1979). Scanning electron microscopy of Tintinnopsis parva: studies on particle accumulation and the striae. J. Protozool. 26: 415-419

Gold, K. (1980). SEM studies of the lorica of various Tintinnina. Scanning electron microscopy/1980/III. SEM Inc., AMF O'Hare, Chicago, p. 537-542

Gold, K., Morales, E. A. (1975). Seasonal changes in lorica sizes and the species of Tintinnida in the New York Bight. J. Protozool. 22: 520-528

Hargraves, P. E. (1981). Seasonal variations of tintinnids (Ciliophora: Oligotrichida) in Narragansett Bay, Rhode Island, USA. J. Plankton Res. 3: 81-91

Hartwig, E. (1973). Die Ciliaten des Gezeiten-Sandstrandes der Nordseeinsel Sylt. II. Ókologie. Akad. Wiss. Lit. (Mainz) Math.-Naturwiss. Kl. Mikrofauna Meeresboden 21: 3-171

Hedin, H. (1975). On the ultrastructure of Favella ehrenbergii (Claparede and Lachmann) and Parafavella gigantea (Brandt), Protozoa, Ciliata, Tintinnida. Zoon 3: 11-18

Hedin, H. (1976). Microtubules and microfilaments in the tintinnid ciliate Ptychocylis minor Jörgensen. Zoon 4: 1-8

Heinbokel, J. F. (1978a). Studies on the functional role of tintinnids in the Southern California Bight. 1. Grazing and growth rates in laboratory cultures. Mar. Biol 47: 177-189

Heinbokel, J. F. (1978b). Studies on the functional role of tintinnids in the Southern California Bight. 2. Grazing rates of field populations. Mar. Biol. 47: 191-197

Heinbokel, J. F., Beers, J. R. (1979). Studies on the functional role of tintinnids in the Southern California Bight. 3. Grazing impact of natural assemblages. Mar. Biol. 52: $23-32$

Hemleben, C., Bé, A. W. H., Anderson, O. R., Tuntivate, S. (1977). Test morphology, organic layers and chamber formation of the planktonic foraminifer Globorotalia menardii (D'Orbigny). J. Foram. Res. 7: 1-25

Karnovsky, M. J. (1965). A formaldehyde-glutaraldehyde fixature of high osmolality for use in electron microscopy. Abstr. 5th Ann. Meet. Am. Soc. Cell. Biol. 137a

Landry, M. R., Hassett, R. P. (1982). Estimating the grazing impact of marine microzooplankton. Mar. Biol. 67 : 283-288

Laval, M. (1971). Mise en evidence par la microscopie électronique d'un organite d'un type nouveau chez les cilies tintinnides. Compt. Rend. Acad. Sci. 273: 1383-1386

Laval, M. (1972). Ultrastructure de Petalotricha ampulla (Fol). Comparaison avec d'autres tintinnides et avec les autres ordres de cilies. Protistologica 8: 369-386

Laval-Peuto, M., Gold, K., Storm, E. R. (1979). The ultrastructure of Tintinnopsis parva. Trans. Am. microsc. Soc. 98 : 204-212

LeBrasseur, R., Kennedy, O. D. (1972). Microplankton in coastal and oceanic areas of the Pacific subarctic water 
mass: a preliminary report. In: Takenouti, A. Y (ed.) Biological oceanography of the northern North Pacific Ocean. Idemistu Shoten, Tokyo, p. 309-321

Nisbet, B. (1984). Nutrition and feeding strategies of Protozoa Croom Helm, London

Pace, M. L., Orcutt, J. D. Jr. (1981). The relative importance of protozoans, rotifers and crustaceans in a freshwater zooplankton community. Limnol. Oceanogr 26: 822-830

Rassoulzadegan, F. (1978). Dimensions et taux d'ingestion des particles consommées par un tintinnide Favella ehrenbergii (Clap et Lachm.) jorg., Cilie Pelagigue Marin. Annls Inst. océanogr. Paris 54: 17-24

Rassoulzadegan, F., Etienne, M. (1981). Grazing rate of the tintinnid Stenosemma ventricosa (Clap and Lachm.) jorg. on the spectrum of the naturally occurring particulate matter from a Mediterranean neritic area. Limnol Oceanogr. 26: 258-270

Robertson, J. R. (1983). Predation by estuarine zooplankton on tintinnid ciliates. Estuar. coast. Shelf Sci. 16: 27-36

Sieburth, J. McN. (1979). Sea microbes. Oxford Univ. Press, Oxford

Small, E. B., Lynn, D. H. (1985). Phylum Ciliophora Doflein, 1901. In: Lee, J. J., Hutner, S. H., Bovee, E. C. (ed.) Illustrated guide to the Protozoa. Soc. of Protozoologists, Allen Press, Inc., Kansas, p. 393-575
Sleigh, M. (1973). The biology of Protozoa. Edward Amold, London

Sorokin, Y. I. (1977). The heterotrophic phase of plankton succession in the Japan Sea. Mar. Biol. 47: 107-117

Spittler, P. (1973). Feeding experiments with tintinnids. Oikos Suppl. 15: 128-132

Stoecker, D. K., Govoni, J. J. (1984). Food selection by young larval gulf menhaden (Brevoortia patronus). Mar Biol. 80 299-306

Stoecker, D., Sanders, N. K. (1985). Differential grazing by Acartia tonsa on a dinoflagellate and tintinnid. J. Plankton Res. 7: 85-100

Stoecker, D., Guillard, R. R. C., Kavee, R. M. (1981). Selective predation by Favella ehrenbergii (Tintinnia) on and among dinoflagellates. Biol. Bull. mar biol. Lab., Woods Hole 160: 136-145

Turner, J. T., Anderson, D. M. (1983). Zooplankton grazing during dinoflagellate blooms in a Cape Cod embayment, with observations of predation upon tintinnids by copepods. P.S.Z.N. Mar. Ecol. 4: 359-374

Vitiello, P. (1964). Contribution à l'etude des tintinnids de la Baie d'Alger. Pelagos 2: 5-42

Voronina, N. M., Sukhanova, I. N. (1976). Food composition in the mass species of Antarctic herbivorous copepods. Okeanologija 16: 1082-1086

This article was presented by Dr. M. Levandowsky; it was accepted for printing on February 26, 1986 